\title{
Oscillation of the even - order delay linear differential equation
}

\section{J. DŽURINA and B. BACULÍKOVÁ}

\section{ABSTRACT.}

In the paper we offer criteria for oscillation of the even order delay differential equation

$$
y^{(n)}(t)+p(t) y(c t)=0
$$

We provide detail analysis of the properties of this equation, we offer necessary and sufficient conditions for oscillation of studied equation and we fulfill the gap in the oscillation theory.

Acknowledgement. This work was supported by Slovak Research and Development Agency under the contract No. APVV-0404-12.

\section{REFERENCES}

[1] Arino, O. and Gyori, I., Necessary and sufficient condition for oscillation of a neutral differential system with several delays, J. Differential Equations, 81 (1989), 98-105

[2] Baculíková, B. and Džurina, J., Oscillation theorems for second order neutral differential equations, Comput. Math. Appl., 61 (2011), 94-99

[3] Baculíková, B. and Džurina, J., Oscillation theorems for second order neutral differential equations, EJQTDE 2011, No. $74,1-13$

[4] Džurina, J., Comparison theorems for nonlinear ODEs, Math. Slovaca, 42 (1992), 299-315

[5] Erbe, L. H., Kong, Q. and Zhang, B. G., Oscillation Theory for Functional Differential Equations, Marcel Dekker, New York, 1994

[6] Hartman, P. and Wintner, A., Linear differential and difference equations with monotone solutions, Amer. J. Math., 75 (1953), 731-743

[7] Kiguradze, I. T. and Chaturia, T. A., Asymptotic Properties of Solutions of Nonatunomous Ordinary Differential Equations, Kluwer Acad. Publ., Dordrecht 1993

[8] Kulenovic, M. R. S., Oscillation of the Euler differential equation with delay, Czech. Math. J., 45 (1995), 1-6

[9] Kusano, T. and Naito, M., Comparison theorems for functional differential equations with deviating arguments, J. Math. Soc. Japan, 3 (1981), 509-533

[10] Ladde, G. S., Lakshmikantham, V. and Zhang, B. G., Oscillation Theory of Differential Equations with Deviating Arguments, Marcel Dekker, New York, 1987

[11] Mahfoud, W. E., Oscillation and asymptotic behavior of solutions of nth order nonlinear delay differential equations, J. Differ. Equ., 24 (1977), 75-98

DePARTMENT OF MATHEMATics

TECHNiCAL UNIVERSITY OF KOŠICE

LETNÁ 9, 04200 KOŠICE, SLOVAKIA

E-mail address: $\{$ blanka.baculikova, jozef.dzurina\}@tuke.sk

Received: 14.06.2013; In revised form: 03.10.2013; Accepted: 23.04.2014

2010 Mathematics Subject Classification. 34K11, 34C10.

Key words and phrases. Even-order differential equations, comparison theorem, oscillation.

Corresponding author: J. Džurina; jozef.dzurina@tuke.sk 